\title{
AUGUST 2020
}

VOLUME 14 ISSUE S2

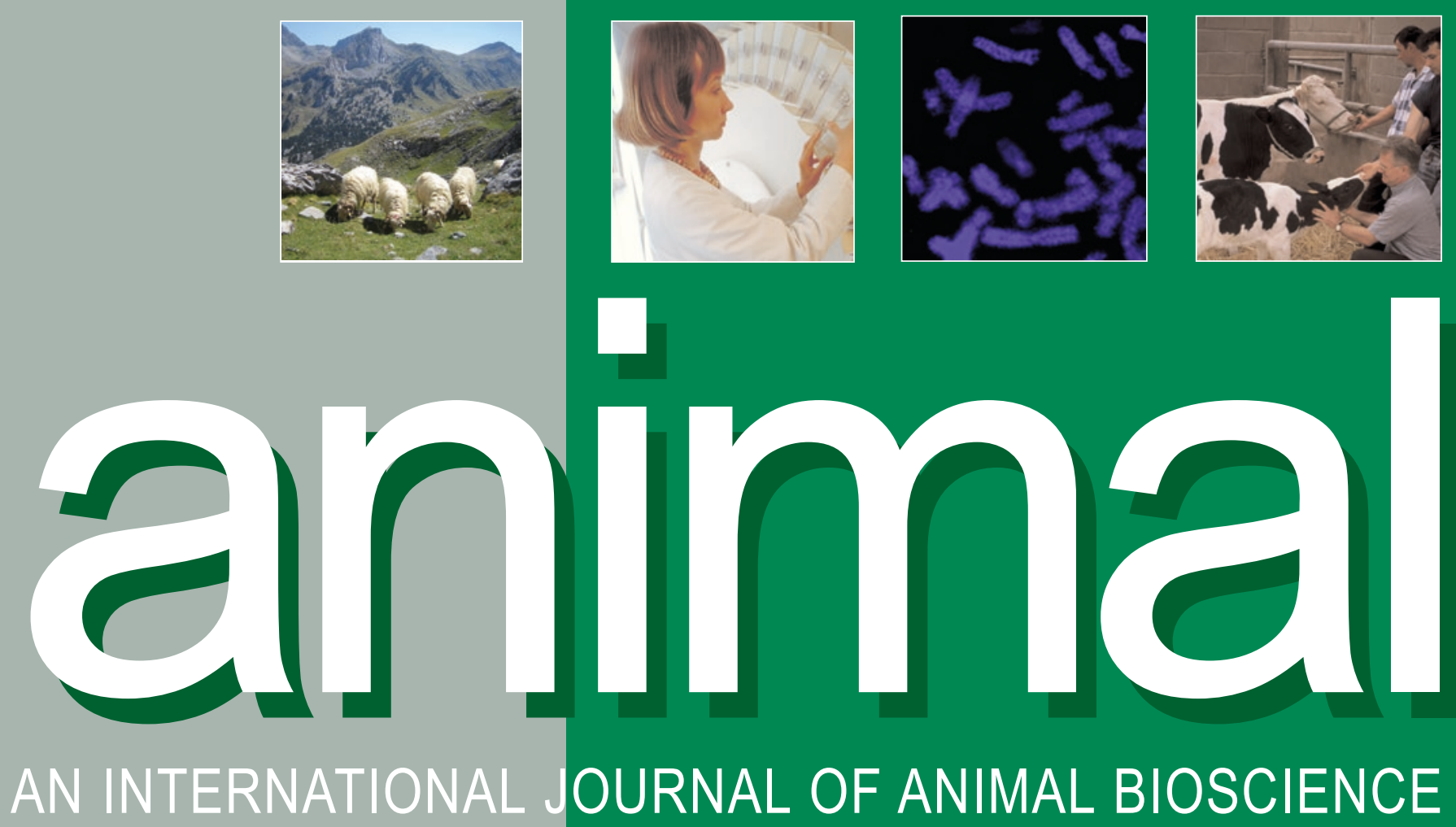

9th Workshop on Modelling Nutrient Digestion and Utilization in Farm Animals (MODNUT)

Guest Editors:

Candido Pomar, Dennis Poppi, Dianne Mayberry, Izabelle Auxiliadora Molina de Almeida Teixeira, Jan Dijkstra, Mark Hanigan, Robert Gous

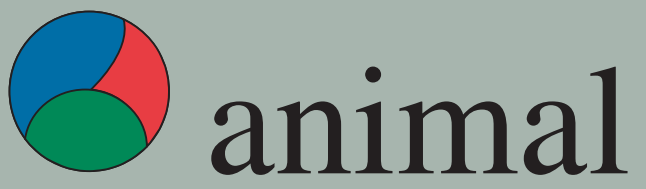




\section{ANIMAL}

Management Board

N. SCOLLAN (Chair); M. MITCHELL,

H. SimMinS, L. SinclaiR (BSAS);

P. Chemineau, M. Gauly, A. Rosati (EAAP);

N. Friggens, O. Hologne, S. INGRAND (INRAE)

\section{Editor-in-Chief}

I. ORTIGUES-MARTY (France)

\section{Editorial Office}

Email: questions@animal-journal.eu

N. MiRAuX (Editorial Assistant),

C. REIGATE (Technical Editor)

\section{Editorial Board}

Breeding and Genetics.

Section Editor: S. RODRIGUEZ-ZAS (USA),

Deputy Section Editor: R. MRODE (UK)

Editors: F. BRITO LOPES (Brazil)

J. GIBSON (Australia),

D. GonZalez-Pena (USA)

N. IBANEZ-ESCRICHE (Spain),

J. SzYDA (Poland), Z. ZHANG (China)

Nutrition - Nonruminants.

Section Editor:

P. Moughan (New Zealand),

Deputy Section Editor:

D. TORRALLARDONA (Spain)

Editors: R. AbdolLAHI (New Zealand),

P. BIKKER (The Netherlands),

N. Corcionivoschi (Northern Ireland),

W. GERRITS (The Netherlands),

T. GIDENNE (France), D. JózefiAK (Poland),

E.-J. Lock (Norway), J. MATTE (Canada),

C. Metges (Germany)

C. Montoya (New Zealand), J. MurRaY (UK),

B. Silva (Brazil), S. TesseraUd (France),

E. Tibaldi (Italy), J. VAN MiLgen (France),

F. WANG (China), B. WiLLIAMs (Australia)

Nutrition - Ruminants.

Section Editor: P. VeRCOE (Australia)

Deputy Section Editor:

R. GeRvals (Canada)

Editors: H. ARCHIMEDE (France)

J. De Boever (Belgium), C. GIRARD (Canada),

K. Kalscheur (USA), D. MCNeILl (Australia),

C. McSWEeney (Australia), J. NeWBold (UK),

D. PACHECO (New Zealand),

M. J. RANILLA (Spain),

T. SCHONEWILLE (The Netherlands)

K.-H. SÛDEKUM (Germany),

I. TeIXEIRA (Brazil), R. XIANG (Australia),

S. ZHAO (China)

\section{Physiology and Functional Biology}

Section Editor:

R. UNGERFELD (Uruguay),

Deputy Section Editor:

I. LOUVEAU (France)

Editors: J.F. AsTURIANO (Spain),

J. Brameld (UK), M. DuARTE (Brazil),

J. Gross (Switzerland), D. KENNY (Ireland),

R.V. KNox (USA), P. LACASSE (Canada),

P. MeRmiLlod (France), P. MozDZIAK (USA),

E. MURANI (Germany),

L. Porte-Nero (Australia), R.D. SAINZ (USA),

J. SANTIAGo-MoRENO (Spain),

J. ShARP (Australia), M. WILKENS (Germany)

Welfare, Behaviour and Health

Management - Welfare and Behaviour

Section Editor: M. CockRAM (Canada),

Deputy Section Editor: M.B. JENSEN

(Denmark),

Editors: B. AMPE (Belgium)

K. HORBACH (USA),

I. De Jong (NL), E. Merlot (France),

H. STRYHN (Canada),

P. T. THOMSEN (Denmark), F. TUYTTENS

(Belgium), E. Von BoreLL (Germany)
Welfare, Behaviour and Health Management - Health Management

Section Editor: M. CockRam (Canada) Deputy Section Editor: C. ENEVOLDSEN (Denmark)

Editors: N. BAREILLE (France),

C. DUCROT (France), M. VAARST (Denmark)

Livestock Farming Systems - Livestock Systems

Section Editor: A. DunCAN (Ethiopia/UK), Deputy Section Editor: M. GAULY (Germany), Editors: L.H. Dossa (Benin),

M. FRASER (UK)

J. HARTUNG (Germany),

N. MIRAGLIA (Italy), S. OOSTING

(The Netherlands), H. PoulSEN (Denmark), J. T. SORENSEN (Denmark)

Livestock Farming Systems - Precision Livestock Farming

Section Editor: I. HALACHMI (Israel)

Editors: S. DRUYAN (Israel),

A. Haeussermann (Germany),

J. MASELYNE (Belgium),

C. Morgan-Davies (UK)

Quality of Animal Products.

Section Editor: P. SCHMIDELY (France),

Deputy Section Editor: B. LEBRET (France)

Editors: A. BALDI (Italy), G. BEE (Switzerland),

M. Campo (Spain), A. Descalzo (Argentina),

K. KLIEM (UK), L. PINOTTI (Italy),

C. RYMER (UK)

\section{Aims and Scope of the journal}

animal publishes the best, innovative and

cutting-edge science that relates to animals

(farmed or managed) used for animal

production, and that is relevant to whole

animal outcomes, and/or to animal

management practices. Papers can be

accepted from all species if they are in, or

contribute knowledge to, animal production

systems. animal is essential reading for all

animal scientists, stakeholders and policy

makers interested in agricultural,

biomedical, veterinary and environmental

sciences with expected impacts on Animal

Production and Productivity, Animal

Welfare, Animal Health, Food Security,

Environment, Climate Change, Product

Quality, Human Health and Nutrition, and

Sustainability of Animal Agriculture and

Livestock Systems. Impacts should be of international relevance.

animal aims to publish novel and original research papers, horizon-scanning reviews and critically informative opinion papers. Papers should consider animal responses, as well as lower or upper levels of understanding, with research spanning from genes to systems. Interactions between levels of approach are encouraged to account for the integrative nature of biological systems. The detailed scope of the journal can be found at www.animal-journal.eu/scope.htm

\section{Submission of Manuscripts}

All manuscripts must be submitted online via the website: http://www.editorial manager.com/animal/

Please consult the full instructions for authors at: https://www.cambridge.org/ core/journals/animal/information/ instructions-contributors

Subscriptions

Animal (ISSN 1751-7311) is published monthly. The subscription price for institutions of Volume 14 (2020) which includes electronic access and delivery by air is $£ 1210, € 1483$ (US \$2366 in the USA, Canada and Mexico); the electronic only price for institutions is $£ 930, € 1210$ (US \$1867 in the USA, Canada and Mexico). Single parts are $£ 116$,
$€ 142$ (US \$227 in the USA, Canada and Mexico), plus postage.

Orders, which must be accompanied by payment, may be sent to a bookseller, subscription agent or direct to the publisher:

Cambridge University Press, Journals

Fulfillment Department, University

Printing House, Shaftesbury Road, Cambridge CB2 8BS, UK; or in the USA

Canada and Mexico: Cambridge University

Press, Journals Fulfillment Department,

One Liberty Plaza, Floor 20, New York,

NY 10006, USA. EU subscribers (outside the UK) who are not registered for VAT should add VAT at their country's rate. VAT registered subscribers should provide their VAT registration number. Japanese prices for institutions are available from Kinokuniya Company Ltd, P. O. Box 55 , Chitose, Tokyo 156, Japan.

Copies of the journal for subscribers in the USA, Canada and Mexico are sent by air to New York to arrive with minimum delay. Periodicals postage paid at New York, NY, and at additional mailing offices. Postmaster: send address changes in the USA, Canada and Mexico to: Animal, Cambridge University Press, Journals Fulfillment One Liberty Plaza, Floor 20, New York, NY 10006. Claims for missing issues should be made immediately on receipt of the subsequent issue.

\section{Advertising}

Advertising queries for all parts of the world except the USA, Canada and Mexico to ad_sales@cambridge.org

Address enquiries in the USA, Mexico and Canada only to: USAdSales@ cambridge.org

\section{Copying}

This journal is registered with the Copyright Clearance Center, 222 Rosewood Drive, Danvers, MA 01923, USA (www.copyright. com). Organizations in the USA who are also registered with CCC may therefore copy material (beyond the limits permitted by sections 107 and 108 of US copyright law) subject to payment to CCC. This consent does not extend to multiple copying for promotional or commercial purposes.

ISI Tear Sheet Service, 3501 Market Street, Philadelphia, PA 19104, USA is authorized to supply single copies of separate articles for private use only.

Organizations authorized by the Copyright Licensing Agency may also copy material subject to the usual conditions. For all other use, permission should be sought from Cambridge or the American Branch of Cambridge University Press.

Internet Access

This journal is included in the Cambridge Journals Online Service which can be found at www.cambridge.org/journals

Front cover images

Mountain scene photograph courtesy of Julian Casasús. Other images ( INRAE Picture Library.

This journal issue has been printed on FSCcertified paper and cover board. FSC is an independent, non-governmental, not-for-profit organization established to promote the responsible management of the World's forests. Please see www.fsc.org for information.

Printed in the UK by Bell \& Bain Ltd., Glasgow. C C Animal Consortium 2020 


\section{animal}

\section{AN INTERNATIONAL JOURNAL OF ANIMAL BIOSCIENCE}

\section{9th Workshop on Modelling Nutrient Digestion and Utilization in Farm Animals (MODNUT)}

Guest Editors:

Candido Pomar, Dennis Poppi, Dianne Mayberry, Izabelle Auxiliadora Molina de Almeida Teixeira, Jan Dijkstra, Mark Hanigan, Robert Gous
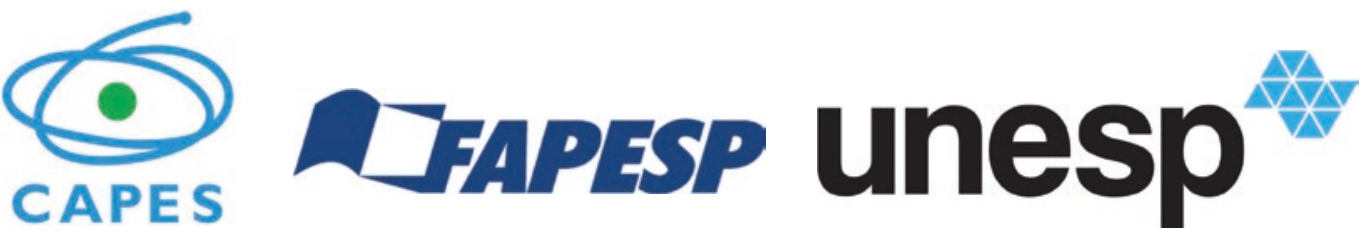

The papers included in this supplement were invited by the Guest Editors and have undergone the standard journal formal review process. They may be cited. 


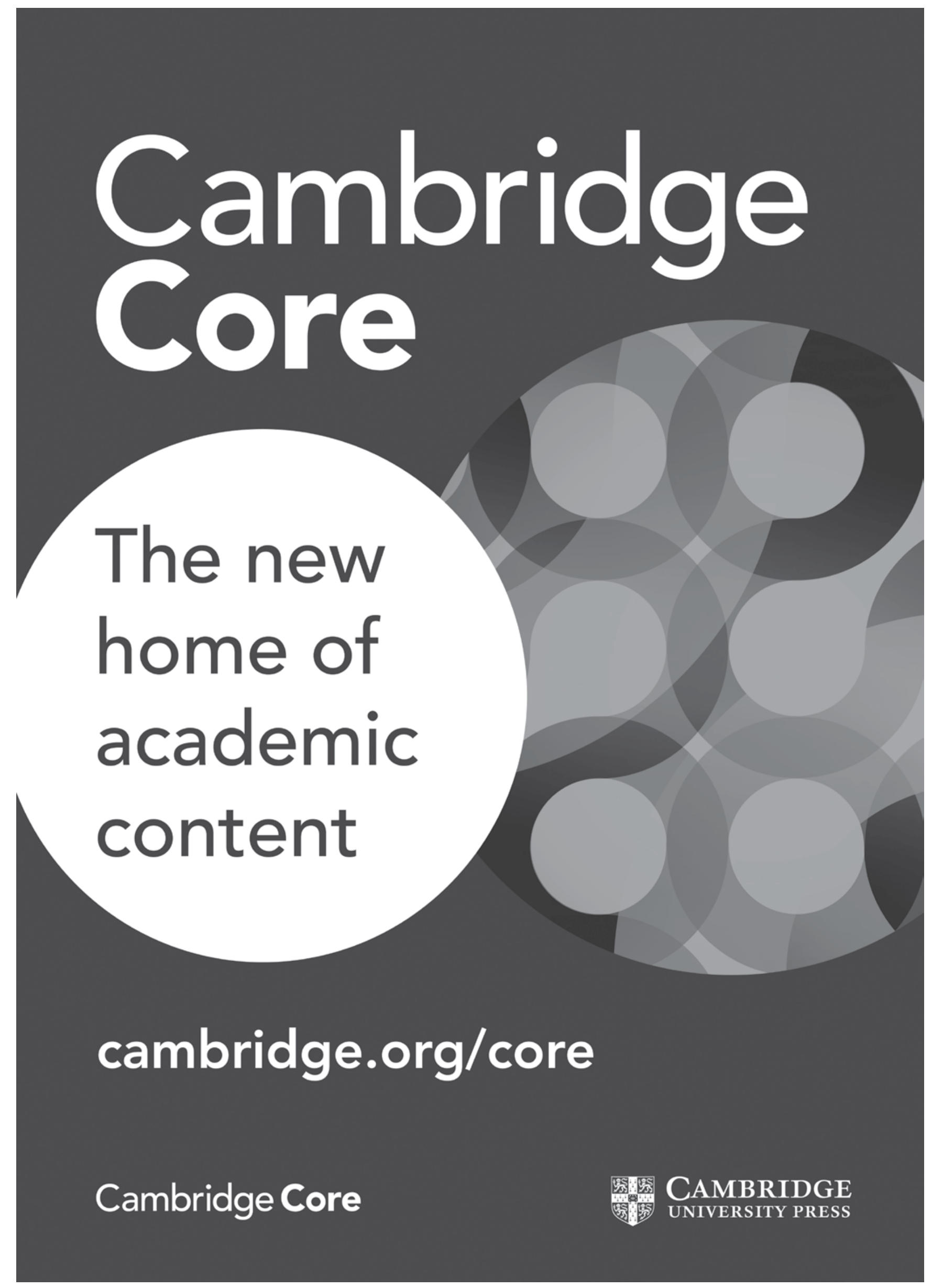

